\title{
Maintaining RNA integrity in a homogeneous population of mammary epithelial cells isolated by Laser Capture Microdissection
}

\author{
Claudia Bevilacqua ${ }^{1,2^{*}}$, Samira Makhzami ${ }^{1,2}$, Jean-Christophe Helbling ${ }^{1,2,4}$, Pierre Defrenaix ${ }^{3}$, Patrice Martin ${ }^{1,2}$
}

\begin{abstract}
Background: Laser-capture microdissection (LCM) that enables the isolation of specific cell populations from complex tissues under morphological control is increasingly used for subsequent gene expression studies in cell biology by methods such as real-time quantitative PCR ( $\mathrm{qPCR}$ ), microarrays and most recently by RNA-sequencing. Challenges are i) to select precisely and efficiently cells of interest and ii) to maintain RNA integrity. The mammary gland which is a complex and heterogeneous tissue, consists of multiple cell types, changing in relative proportion during its development and thus hampering gene expression profiling comparison on whole tissue between physiological stages. During lactation, mammary epithelial cells (MEC) are predominant. However several other cell types, including myoepithelial (MMC) and immune cells are present, making it difficult to precisely determine the specificity of gene expression to the cell type of origin. In this work, an optimized reliable procedure for producing RNA from alveolar epithelial cells isolated from frozen histological sections of lactating goat, sheep and cow mammary glands using an infrared-laser based Arcturus Veritas LCM (Applied Biosystems ${ }^{\circledast}$ ) system has been developed. The following steps of the microdissection workflow: cryosectioning, staining, dehydration and harvesting of microdissected cells have been carefully considered and designed to ensure cell capture efficiency without compromising RNA integrity.

Results: The best results were obtained when staining $8 \mu \mathrm{m}$-thick sections with Cresyl violet ${ }^{\oplus}$ (Ambion, Applied Biosystems ${ }^{\oplus}$ ) and capturing microdissected cells during less than 2 hours before RNA extraction. In addition, particular attention was paid to animal preparation before biopsies or slaughtering (milking) and freezing of tissue blocks which were embedded in a cryoprotective compound before being immersed in isopentane. The amount of RNA thus obtained from ca.150 to 250 acini $\left(300,000\right.$ to $600,000 \mu^{2}$ ) ranges between 5 to $10 \mathrm{ng}$. RNA integrity number (RIN) was ca. 8.0 and selectivity of this LCM protocol was demonstrated through qPCR analyses for several alveolar cell specific genes, including LALBA ( $\alpha$-lactalbumin) and CSN1S2 ( $\alpha_{\mathrm{s} 2}$-casein), as well as Krt14 (cytokeratin 14), CD3e and CD68 which are specific markers of MMC, lymphocytes and macrophages, respectively.
\end{abstract}

Conclusions: RNAs isolated from MEC in this manner were of very good quality for subsequent linear amplification, thus making it possible to establish a referential gene expression profile of the healthy MEC, a useful platform for tumor biomarker discovery.

\section{Background}

One of the main challenges biologists currently face is overcoming the problem of tissue heterogeneity to further understand organ function. It is crucial to distinguish which cell populations produce specific molecules

\footnotetext{
* Correspondence: claudia.bevilacqua@jouy.inra.fr

'INRA, UMR1313 Unité Génétique Animale et Biologie Intégrative, équipe « Lait, Génome \& Santé » F-78350 Jouy-en-Josas, France

Full list of author information is available at the end of the article
}

or to get relevant expression profiles reflecting in vivo status.

Milk is synthesized in mammary gland during lactation and though this process has been thoroughly studied, we still do not know precisely what mechanisms are involved in the intracellular transport and secretion of milk components, including supra-molecular structures, such as casein micelles $[1,2]$ which are assembled

\section{Biomed Central}


during their transit within the mammary epithelial cell (MEC).

Mammary parenchyma consists of secretory alveoli organized into lobules and interconnected by a system of branching ducts separated from adipocytes by multiple layers of fibroblastic connective tissue. In the duct and alveoli, the mammary epithelium is organized into two layers, a basal layer of myoepithelial cells (MMC) and a luminal layer of MEC that secretes milk [3]. The extra cellular matrix comprises non-epithelial cells: fibroblast, endothelial cells, lymphocytes, adipocytes, neurons, myocytes, etc. Thus, the adult mammary gland during lactation is a complex tissue consisting of several cell types. During lactation, epithelial cells are predominant relative to adipocytes which are conversely more abundant in the nulliparous gland [3]. Since both cell types are involved in lipid metabolism using the same metabolic pathways and enzymes, it becomes difficult to sort out the function of each cell type $[4,5]$.

Advances in molecular biology have provided new tools, including gene expression profiling, to analyze mechanisms controlling mammary gland development and differentiation [6,7] and regulating milk synthesis and secretion. However, most of the studies performed to date on healthy mammary gland have been done without taking into account the complexity of this tissue with the exception of Grigoriadis et al. [8]. On the other hand, a number of integrated approaches combining advanced molecular technologies have been applied to analyze human breast cancer [9-11], but few studies were carried out on healthy breast tissue compared to carcinoma [12,13]. Analysis of bulk mammary tissue homogenates leads inevitably to an average measurement of biomolecules (RNA and proteins) from the various cell types it is made of. Therefore, there is a high risk that changes in the expression of genes involved in MEC functions could be masked by their expression in surrounding cells. For example, genes involved in lipid biosynthesis are expressed in MEC and adipocytes but not regulated in the same way during lactation $[14,15]$.

Therefore, to accurately and reliably follow molecular changes occurring in MEC for comparison purposes between physiologically different stages and genetically or environmentally perturbed systems, it is necessary to isolate MEC preserving biomolecule (RNA and proteins) integrity.

Different techniques, such as immunomagnetic separation [16-19], cell sorting [20] and tissue-depletion [15] have been used to isolate more or less homogeneous populations of MEC from milk or mammary tissue. MECs isolated from milk are easy to collect noninvasively and constitute a valuable source of material for analyzing mammary transcript profile during lactation. Although it has been claimed that milk MECs reliably reflect the activity of the mammary epithelium in goats and cattle [21,22], one can expect that cells out of their physiological context and faced with stressful purification protocols very likely induce adaptive changes modifying their expression profile. Differentially expressed membrane antigens have been used to flow-sort viable luminal epithelial and MMC from freshly disaggregated adult virgin rat mammary parenchyma [23].

Another means to obtain MEC homogeneous populations is from cell culture. However, one major obstacle to molecular biological studies of MEC is the lack of established cell lines that secrete, or can be induced to secrete, fat globules and milk proteins [24]. While culture systems have helped to identify some of the factors controlling growth $[25,26]$, morphogenesis $[27,28]$, functional differentiation [29] and tumorigenesis $[30,31]$ of the rodent mammary gland, the heterogeneous cellular composition of primary cultures derived from the intact mammary parenchyma [32,33] complicates the interpretation of responses in vitro. In addition, it is well-established that MEC in culture are subjected to dedifferentiation [34].

Laser Capture Microdissection (LCM), first described by Emmert-Buck et al. [35] is now well established as a powerful tool for isolating cells of interest under morphological control from heterogeneous tissues. Major issues that should be addressed when using such a sorting approach are the amount and integrity of biological material extracted for reliable subsequent analyses of biomolecules (DNA, RNA and proteins). Amplification of nucleic acids is still possible as well, provided integrity is preserved. RNA degradation remains one of the main concerns since it can extend dramatically, depending upon the tissue. Also, it may significantly impact gene expression profiling. Frozen tissues are recommended for RNA recovery.

Nevertheless, LCM is an appealing technique, but it introduces additional methodological hurdles, including tissue handling (fixation, storage and staining) and maintenance of molecular integrity. The success of a microdissection experiment first depends upon the ability to distinguish cell types of interest from their morphological features. Immunological labelling may be required and used to assist in the identification of cells. In other words, if gene expression experiments are targeted, the challenge is to design a global protocol ensuring acceptable tissue morphology to facilitate isolation of cells while preserving accessibility and integrity of RNA, keeping in mind that this is critically tissuedependent.

Successful application of LCM in transcriptomic analyses relies upon three critical factors: good tissue morphology, capture efficiency, and maintenance of RNA molecular integrity. Effective balancing of these three 
factors is required to recognize regions and obtain reliable transcriptomic results. Since ruminant mammary gland is one of the richest tissues in RNAse activity, classical protocols require accommodation to preserve RNA from RNase (endogenous and exogenous) and keep it intact in captured cells. This study was carried out to address these issues with the aim of developing a convenient and reproducible protocol to isolate MECs from ruminants (goat, sheep and cow) lactating mammary gland, preserving tissue morphology and RNA integrity, to develop a comprehensive overview of the genome expressed in MECs in their physiological environment.

Given that recent studies [36-38] reported the effects of tissue manipulation on RNA quality and gene expression, and that each tissue requires specific protocol for reliable results, we have evaluated the impact of the main critical steps (sampling, freezing, cryosectioning, staining, dehydration, and microdissection) during slide preparation and capture of MEC. In addition, we examined selectivity of this technique in evaluating enrichment in MEC as well as contamination by other surrounding cell types such as MMC, and immune cells (macrophages and lymphocytes) using qPCR.

\section{Methods}

\section{Animals and tissue collection (sampling)}

Surgical and experimental procedures were performed in compliance with the policies of INRA's Animal Care Committee. Mammary tissue was sampled from 5 goats, 2 ewes and 1 cow euthanized under safe and painless conditions, at the middle of lactation after milking and slaughtering. To preserve morphology and RNA quality we applied two different methods of freezing (liquid nitrogen or cold isopentane) immediately after collection with and without embedding medium as follows: the collected tissue was washed in cold PBS solution, 3-5 $\mathrm{mm}$ pieces of tissue were cut 3 and embedded in $\mathrm{OCT}^{\circ}$ (TissuTek ${ }^{\mathrm{nt}}$ ) in a cryomold of $1 \mathrm{~cm}^{3}$ (Bayer ${ }^{\mathrm{rn}}$ ) and immediately immersed in liquid nitrogen or in SnapFrost ${ }^{\mathrm{tm}}$ system (Alphelys, France) containing cold isopentane at $-80^{\circ} \mathrm{C}$. Alternatively, some pieces were directly introduced in empty $1.5 \mathrm{ml}$ cryotubes and immediately frozen in the same way (liquid nitrogen or SnapFrost ${ }^{\text {tax }}$ system). Samples were stored at $-80^{\circ} \mathrm{C}$ until further processing. The time delay between slaughtering and tissue freezing was less than 20 minutes.

\section{Slide preparation: cryo-cutting and dehydration}

Frozen tissue blocks were mounted on the cryostat stage (Thermo Shandon, France) set at $-20^{\circ} \mathrm{C}$. Before transfer, the working environment was treated to be RNAse free and glass slides (uncoated, LLR2-45, CML, France) were pre-cleaned with RNAse Zap ${ }^{\mathrm{m}}$ (Ambion, Applied
Biosystems $\mathrm{s}^{\circ}$ ) and rinsed in three baths of distilled water before a final bath in 70\% ethanol. To test whether the effect of slide temperature plays a key role in detachment of MEC from glass slides during the laser-capture process, pre-cleaned slides were chilled (on ice or at $4^{\circ}$ C) or not (room temperature) before transfer. Manufacturers' and published protocols recommend cutting 5 to $12 \mu \mathrm{m}$ section thicknesses. Tissue sections were $8 \mu \mathrm{m}$ thick, a compromise to ensure an optimal RNA yield preserving morphology as well as dehydration and lasercapture process efficiency.

Only one section was mounted on each apposing slide. To assess the possibility of conserving slides (few hours to several days) after section transfer, two different methods of cold storage were tested: after cutting, the slides were immersed in cold $75 \%$ ethanol and placed at $-20^{\circ} \mathrm{C}$ or put directly into a tube containing desiccant and stored at $-80^{\circ} \mathrm{C}$. To avoid RNA degradation, each step of the slide preparation process was performed as quickly as possible. Water was RNAse free. Bottles of absolute ethanol (SIGMA-ALDRICH, France) and MXylene, anhydrous, >99\% (SIGMA-ALDRICH, France) were opened just before use to dehydrate a maximum number of 8 slices a day to ensure proper dehydration. Sections were stained using Histogene $e^{\otimes}$ staining solution (Arcturus, Applied Biosystems ${ }^{\circ}$ ) or Cresyl violet ${ }^{\circ}$ (LCM staining kit Ambion, Applied Biosystems ${ }^{\circ}$ ). Different protocols for dehydration and staining of frozen mammary sections were compared (Table 1). They were assessed looking at morphology and RNA integrity. After dehydration, slides were kept dehydrated 15 min or more $(\max 3 \mathrm{~h}$ ) in a vacuum.

To preserve the quality of RNA during staining, without ruining the morphology, we tried to add RNA protectors (enzymatic or chemical) used commonly to block RNAse activity, before HistoGene ${ }^{\circ}$ staining. Two chemical protectors were used: RNA later (Ambion, protocol $\mathrm{N}^{\circ} 3$ ) or RCL2 ${ }^{\circ}$ (Alphelys, France, protocols $\mathrm{N}^{\circ}$ 4 and 5), a new fixative which preserves morphology and nucleic acid integrity. In protocols $\mathrm{N}^{\circ} 3$ to $5,100 \mu \mathrm{l}$ of RCL2 ${ }^{\circ}$ or RNA later ${ }^{\circ}$ were dropped on the tissue section just before staining, to react for $30 \mathrm{~s}$ and removed by tapping the slide on an absorbent paper. RNase out (Invitrogen, Applied Biosystems ${ }^{\circ}$ ) or RNAsin (Promega) were prepared $(2.5 \mu \mathrm{l}$ at $40 \mathrm{U} / \mu \mathrm{l}$, in $100 \mu \mathrm{l}$ final of HistoGene ${ }^{\circ}$ ) and added on slice for $15 \mathrm{~s}$ during staining step.

\section{Laser Capture Microdissection}

The LCM process was carried out using the Veritas Microdissection Arcturus system and software (Applied Biosystems ${ }^{\circ}$ ). Capture, which is the gentlest technique and thus maximizing biomolecules integrity, was performed under $40 \times$ or $100 \times$ magnifications using 
Table 1 Different protocols tested to optimize tissue section preparation before laser capture microdissection of mammary epithelial, yield and integrity of RNA extracted from microdissected cells

\begin{tabular}{|c|c|c|c|c|c|c|c|c|}
\hline & $N^{\circ} 1$ & $N^{\circ} 2$ & $N^{\circ} 3$ & $N^{\circ} 4$ & $N^{\circ} 5$ & $N^{\circ} 6$ & $N^{\circ} 7$ & $N^{\circ} 8$ \\
\hline Ethanol 95\% & & & & & & $30 \mathrm{~s}$ & & \\
\hline Ethanol 75\% & $30 \mathrm{~s}$ & $30 \mathrm{~s}$ & $30 \mathrm{~s}$ & $30 \mathrm{~s}$ & $30 \mathrm{~s}$ & $30 \mathrm{~s}$ & $60 \mathrm{~s}$ & $30 \mathrm{~s}$ \\
\hline Ethanol 50\% & & & & & & $20 \mathrm{~s}$ & $20 \mathrm{~s}$ & \\
\hline RNA protector & & & $\begin{array}{c}\text { RNA later }^{\circledast} \\
100 \mu \mathrm{l} \\
30 \mathrm{~s}\end{array}$ & $\begin{array}{c}\mathrm{RCL}^{\odot} \\
100 \mu \mathrm{l} \\
30 \mathrm{~s} \\
\end{array}$ & $\begin{array}{c}\mathrm{RCL}^{\oplus} \\
100 \mu \mathrm{l} \\
30 \mathrm{~s}\end{array}$ & & & \\
\hline Water & + & & $30 \mathrm{~s}$ & $30 \mathrm{~s}$ & & & & + \\
\hline Staining & $\begin{array}{c}\text { HistoGene }^{\oplus} \\
15 \mathrm{~s}\end{array}$ & $\begin{array}{l}\text { HistoGene } \\
10 \mathrm{~s}\end{array}$ & $\begin{array}{l}\text { HistoGene }{ }^{\circledast} \\
10 \mathrm{~s}\end{array}$ & $\begin{array}{l}\text { HistoGene }{ }^{\ominus} \\
10 \mathrm{~s}\end{array}$ & $\begin{array}{l}\text { Cresyl Violet }^{\oplus} \\
20 \mathrm{~s}\end{array}$ & $\begin{array}{c}\text { Cresyl Violet }^{\oplus} \\
20 \mathrm{~s}\end{array}$ & $\begin{array}{c}\text { Cresyl Violet }^{\oplus} \\
20 \mathrm{~s}\end{array}$ & - \\
\hline Ethanol 50\% & & & & & & $20 \mathrm{~s}$ & $5 \mathrm{~s}$ & \\
\hline Water & + & & & & & & & + \\
\hline Ethanol 75\% & $30 \mathrm{~s}$ & $5 \mathrm{~s}$ & $5 s$ & $5 s$ & $5 s$ & $30 \mathrm{~s}$ & $30 \mathrm{~s}$ & $30 \mathrm{~s}$ \\
\hline Ethanol 95\% & $2 \times 1 \mathrm{~m}$ & $2 \times 1 \mathrm{~m}$ & $2 \times 1 \mathrm{~m}$ & $2 \times 1 \mathrm{~m}$ & $2 \times 1 \mathrm{~m}$ & $30-40 s$ & $2 \times 1 \mathrm{~m}$ & $2 \times 1 \mathrm{~m}$ \\
\hline Ethanol 100\% & $2 \times 1 \mathrm{~m}$ & $2 \times 1 \mathrm{~m}$ & $2 \times 1 \mathrm{~m}$ & $2 \times 1 \mathrm{~m}$ & $2 \times 1 \mathrm{~m}$ & $30-40 s$ & $2 \times 1 \mathrm{~m}$ & $2 \times 1 \mathrm{~m}$ \\
\hline Xylene & $2 \times 5-10 m$ & $2 \times 5-10 m$ & $2 \times 5-10 m$ & $2 \times 5-10 m$ & $2 \times 5-10 m$ & $2 \times 5-10 m$ & $2 \times 5-10 m$ & $2 \times 5-10 \mathrm{~m}$ \\
\hline Time of LCM & $30-40 \mathrm{~m}$ & $30-40 \mathrm{~m}$ & $30-40 \mathrm{~m}$ & $40-50 \mathrm{~m}$ & $40-50 \mathrm{~m}$ & $40-90 \mathrm{~m}$ & $40-90 \mathrm{~m}$ & $30 \mathrm{~m}$ \\
\hline RNA integrity $(\triangle R \mid N)$ & -3.5 to -6 & -3 to -4 & -2 & -2 to -3 & -0.5 to -1 & -0.5 to 1 & -0.5 to -1 & -2 \\
\hline Morphology & ++++ & +++ & - - & +++ & +++ & ++ & +++ & \\
\hline
\end{tabular}

In protocols 1 to 4 tissue sections were stained using the HistoGene ${ }^{\circledR}$ LCM frozen section Staining Kit (Arcturus). Cresyl Violet ${ }^{\circledast}$ staining (protocols 5 to 7 ) using Ambion LCM staining Kit provides good morphology and yields high quality RNA. The best protocol was determined to be No.7 (framed and bold), because of the high RNA integrity and morphology and because it was easier to handle without any RNA protector and quicker to perform.

CapSure LCM macrocaps (Arcturus, Applied Biosystems ${ }^{\circ}$ ). IR Laser setting was chosen to maximize the size of the laser spot in the middle of alveoli (luminal side in which MEC are arranged in a monolayer epithelium) without contaminating the sample with non-target-tissue (MMC or interlobular stroma). Laser setting ranged between 75 to $90 \mathrm{~mW}$ in power, 1,300 to $3,500 \mu \mathrm{sec}$ in duration, and $200 \mathrm{mV}$ in intensity. Efficiency of microdissection was evaluated by examining the cap after capture and the tissue section remaining on the slide before and after lifting off the cap: if necessary, the non target tissue can be removed directly on the cap by lower power UV laser (2-5 $\mathrm{mW})$.

The critical time limit for capture was estimated by examining RNA integrity and was evaluated from 30 minutes to 2 hours. The corresponding target area was between 300,000 and $600,000 \mu \mathrm{m}^{2}$ (around 150 to 200 acini).

\section{RNA extraction}

Total RNA was extracted from captured cells using the PicoPure ${ }^{\circ}$ RNA Isolation Kit (Arcturus, Applied Biosystems $s^{\circledR}$ ) according to the manufacturer's instruction protocol, including on-column RNase-free DNase I treatment (Qiagen S.A.- France, Courtaboeuf). CapSure macrocaps with captured cells were inserted into RNase-free $500 \mu \mathrm{l}$ microcentrifuge tube containing $25 \mu \mathrm{l}$ of extraction buffer (XB). The tubes were inverted to allow the reaction between the buffer and the surface of the cap. RNAs were extracted from scraped sections (tissue remaining on the slide after capture) by pipetting $50 \mu \mathrm{l}$ of XB buffer onto the remaining tissue on the glass slide and gently scraped off and transferred in RNase-free $500 \mu \mathrm{l}$ microcentrifuge tube. RNAs from cap and section scrapes were eluted respectively with $15 \mu \mathrm{l}$ and $30 \mu \mathrm{l}$ of elution buffer (EB). To assess RNA quality of tissue before manipulation, one cryo-section of mammary tissue was immediately treated to extract RNA using the same protocol as that for section scrapes after LCM.

\section{RNA quality control and CDNA synthesis}

Purity, concentration and integrity of total RNA isolated in this manner were assessed using two independent techniques. RNA purity was evaluated by absorbance readings (Ratio A260/A230 and A260/A280) using the NanoDrop ND-1000 spectrophotometer (Thermo Fisher Scientific, Wilmington, DE). The fluorimetric method and micro-capillary electrophoresis device developed by Agilent Technologies was chosen to determine RNA concentration and quality with RNA 6000 pico LabChip Kit in the Agilent Bioanalyzer 2100 system. Quality was evaluated using the RNA Integrity Number (RIN) value introduced by Agilent [39].

First-strand cDNA was synthesized from 5-10 ng total RNA primed with oligo $(\mathrm{dT})_{20}$ and random primers 
(3:1, v/v) using Superscript III reverse transcriptase (Invitrogen, Applied Biosystems ${ }^{\odot}$ ) according to manufacturer's instructions. Then, $1 \mu \mathrm{l}$ of RNase $\mathrm{H}(2 \mathrm{U} / \mu \mathrm{l}$, Invitrogen) was added and incubated $20 \mathrm{~min}$ at $37^{\circ} \mathrm{C}$ to remove RNA. The obtained cDNA was stored at $-20^{\circ} \mathrm{C}$ before qPCR.

\section{Determination of MEC enrichment by LCM using qPCR}

To estimate MEC enrichment obtained after LCM, CSN1S2 and LALBA transcripts, two specific markers of MEC, were quantified using qPCR (SYBR Green chemistry). Two internal control genes, S24 ribosomal protein (RPS24) and cyclophylin (PPIA) were quantified for accurate normalization of data [40].

Primers used were previously described $[7,40]$ and qPCR systems were designed to quantify specific markers for MMC (Krt14), lymphocytes (CD3e) and macrophages (CD68). We also quantified transcripts from Fatty Acid Synthase $(F A S N)$ which is expressed in several cell types including MEC and adipocytes.

Comparing the structural organization of encoding genes across species (human, mouse and ruminants) and mRNA sequences at exon-exon junctions, we identified highly conserved regions on which primer pairs were designed, using Primer Express Software, version 2.0 (Applied Biosystems ${ }^{\bullet}$ ). Primers were designed and purchased from Eurofins Genomics (France) to amplify goat, sheep and cow genes (Table 2). Amplification reactions were run (in triplicate) on an ABI PRISM 7900 HT Sequence Detection System (Applied Biosystems ${ }^{\oplus}$ ). First, primers efficiency was validated with a standard curve of four serial dilution points of a scraped section cDNA pool (ranging from $1000 \mathrm{pg}$ to $1 \mathrm{pg}$ of

Table 2 Primers used in this study

\begin{tabular}{ll}
\hline RPS24 F & TT GCC AGC ACC AAC GTT G \\
\hline RPS24 R & AAG GAA CGC AAG AAC AGA ATG AA \\
\hline PPIA F & TGA CTT CAC ACG CCA TAA TGG T \\
\hline PPIA R & CAT CAT CAA ATT TCT CGC CAT AGA \\
\hline CSN152 F & CTG GTT ATG GTT GGA CTG GAAAA \\
\hline CSN1S2 R & AAC ATG CTG GTT GTA TGA AGT AAA GTG \\
\hline Krt14 R & CCC AGC TCA GCA TGA AAG C \\
\hline CD3e F & AGC GGC CTT TGG TCT CTT C \\
\hline CD3e R & ACG CTGT ACC TGA AAG CAA GA \\
\hline CD68 F & AAT ACA CCA GCA GCA GCA AG CTG CTC TCC CTG AAG CTA CA \\
\hline CD68 R & CAT TGG GAC AAG AGA AAC TTG GT \\
\hline FASN F & ACA GCC TCT TCC TGT TTG ACG \\
\hline FASN R & CTC TGC ACG ATC AGC TCG AC
\end{tabular}

Each pair of primers amplifies the target CDNA in its $3^{\prime}$ region. Primer pairs were designed with the Primer Express Software v2.0 (Applied Biosystems) except for RPS24 primers which were manually designed. total RNA reverse transcripts), and a no template control (NTC). qPCR amplification mixture $(20 \mu \mathrm{L})$ contained $5 \mu \mathrm{L}$ single strand cDNA template diluted 4 times after reverse-transcription, $10 \mu \mathrm{L} 2 \times$ Power SYBR Green PCR Master Mix buffer (Applied Biosystems ${ }^{\circ}$ ) and $1.2 \mu \mathrm{L}$ forward and reverse primers $(5 \mu \mathrm{M})$ to reach a final primer concentration of $300 \mathrm{nM}$. After optimization of qPCR systems (efficiency -3.32 to -3.4), we used the $\Delta \Delta \mathrm{Ct}$ method and RQ Manager Software (Applied Biosystems, version 2.3), as well as in the relative expression software tool (REST $2009 \mathrm{~V} 2.0 .13^{\odot}$, Qiagen), to compare expression of each gene between captured cells and its scraped tissue, following the MIQE guidelines [41].

\section{Statistical analysis}

Reliability of reference genes (RPS24 and PPIA) was evaluated with GeNorm Visual Basic application for Microsoft Excel as described by [42].

The relative expression for each gene of interest between caps versus scraped tissues was tested for significance by a randomized test implemented in the relative expression software tool (REST $2009 \mathrm{~V} 2.0 .13^{\odot}$, Qiagen), based on Pair Wise Fixed Reallocation Randomized Test $^{\oplus}$ [43].

\section{Results and discussion}

The main concerns when using LCM to analyse gene expression of a specific cell type is first to efficiently and selectively capture the right cells and second to obtain RNA of good quality. To address these issues and to optimize a LCM experimental design for mammary tissue which is highly heterogeneous and rich in endogenous RNase, a systematic approach was undertaken to evaluate the impact of different critical steps and parameters from tissue sampling and freezing to dehydration (essential when using capture technology) on cell isolation and RNA yield and integrity.

\section{Freezing conditions and tissue morphology}

In this study, ca. 150 slides of tissue sections were cut from 8 mammary glands taken on three different ruminant species: goat, sheep and cow. The impact of the different steps of slide preparation was evaluated and we observed that the early steps, mainly sampling, freezing, cutting and staining of tissue, play a crucial role for a consistent success in capture of alveoli MEC from mammary sections.

Morphology of mammary tissue and RNA quality (RIN value) obtained with or without $\mathrm{OCT}^{\oplus}$ using two different frozen conditions, liquid nitrogen and cold isopentane, are shown in Figure 1. Whereas RNA integrity was preserved under both conditions (RIN for scraped tissue ranged between 8.5 and 9.5), morphology of 


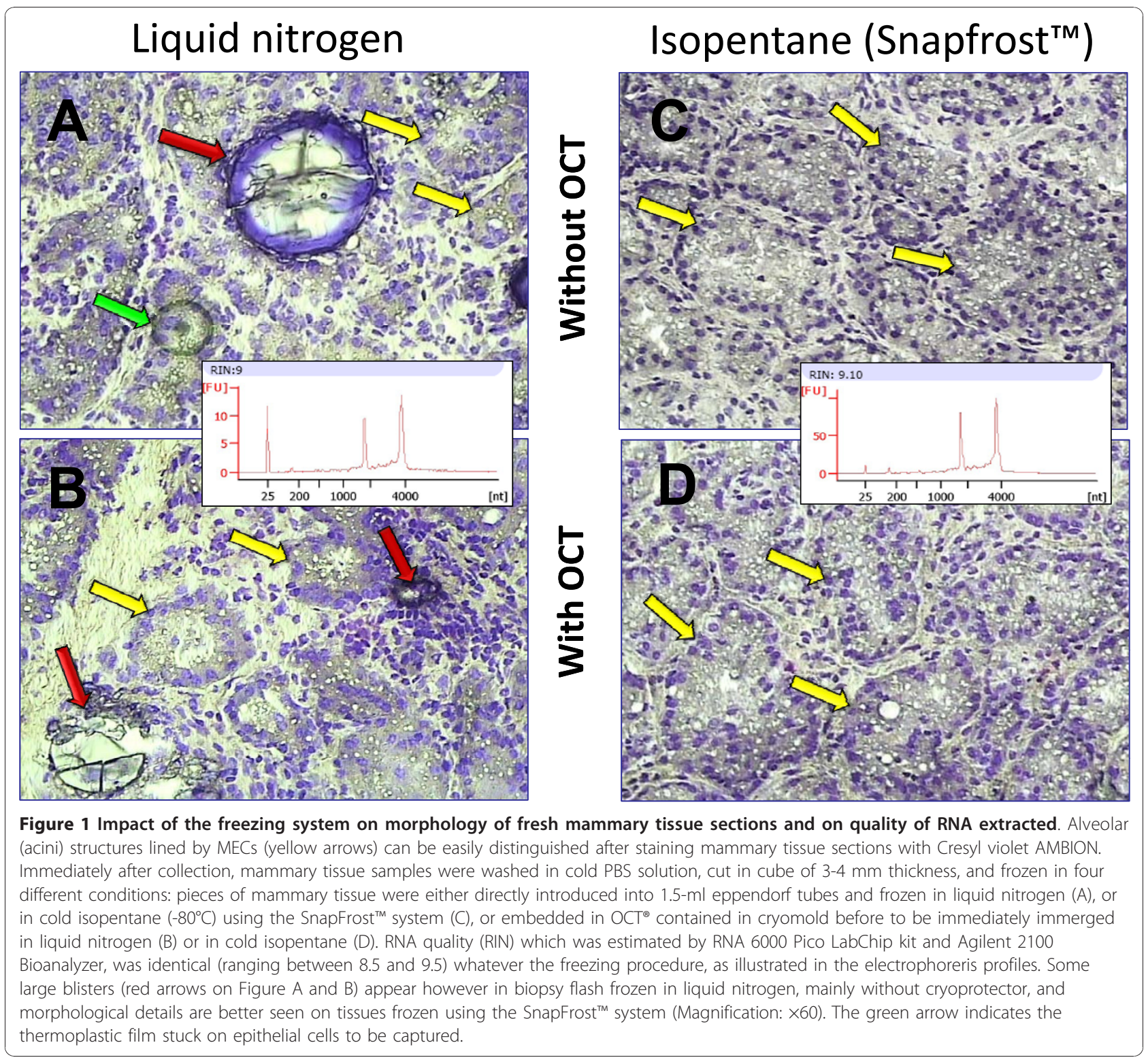

mammary sections frozen in isopentane using the SnapFrost $^{\text {ta }}$ system (Figure 1C and 1D) was better than for tissue frozen in liquid nitrogen (Figure 1A and 1B). Total immersion of $\mathrm{OCT}^{\odot / t i s s u e / c r y o m o l d ~ i n ~ l i q u i d ~}$ nitrogen results in loss of morphological details (Figure 1B) and some morphological artifacts appear in mammary tissue compared to immersion in isopentane (Figure 1C). Rapid freezing in isopentane at $-80^{\circ} \mathrm{C}$ is commonly recognized to provide good morphology and molecular preservation mainly because $-80^{\circ} \mathrm{C}$ is a temperature low enough to prevent the formation of large crystals damaging tissues. In addition, contrary to liquid nitrogen, isopentane does not outgas violently in contact with tissue samples and thereby eliminates the risk of fractures which are opportunities for immediate and long term degradation during storage and at thawing. Total immersion of $\mathrm{OCT}^{\circ}$ embedded tissues into liquid nitrogen resulted in cracked $\mathrm{OCT}^{\circ}$ and formation of bubbles within the specimen.

This phenomenon is amplified when tissue is frozen without $\mathrm{OCT}^{\circ}$ in liquid nitrogen (Figure 1A). Large morphological artifacts such as scratch marks or blisters are observed and impaired correct IR laser impacts during LCM. Consequently, a precise capture due to a different distance between the bottom of cap and tissue section became difficult. In contrast, the SnapFrost ${ }^{\text {tw }}$ system which is a cryo-bath allowing a control temperature of isopentane $\left(-80^{\circ} \mathrm{C}\right)$, reduced freezing-fixation artifact: blocks showed a good morphology and mainly a reliable quality of tissue. 


\section{Slide at room temperature}

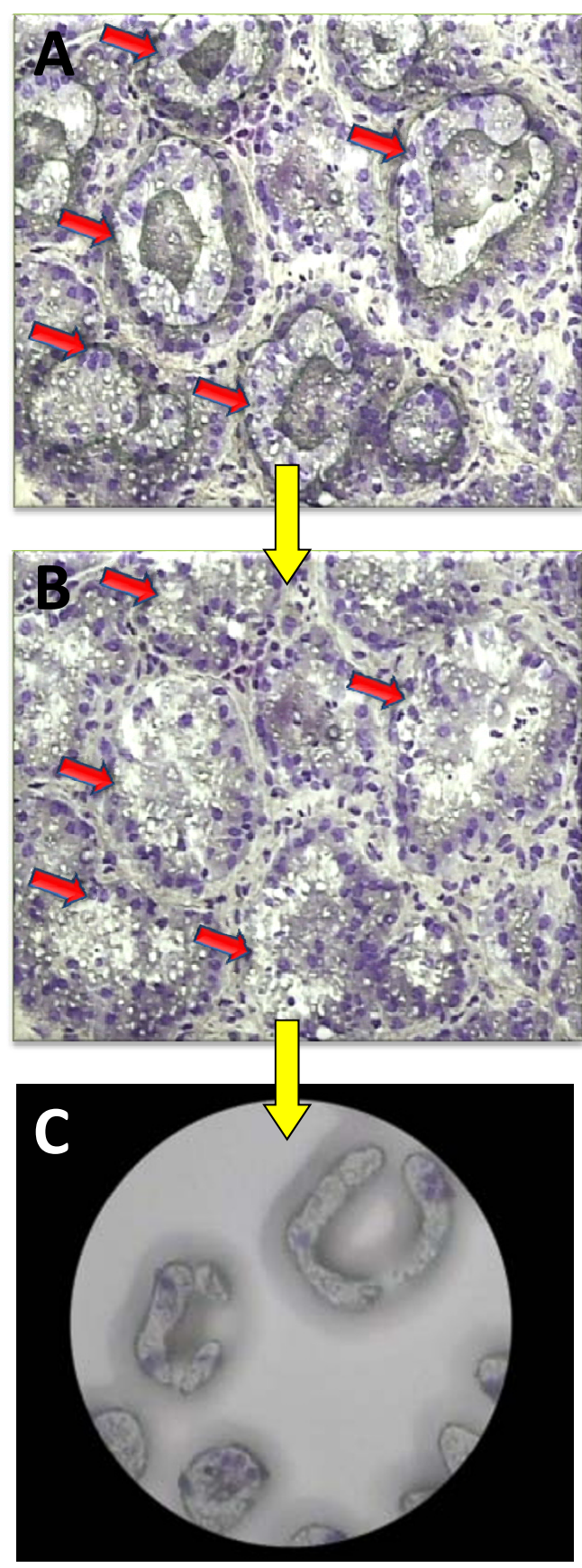

Amount of RNA: 0 to $1 \mathrm{ng}$
Slide on ice

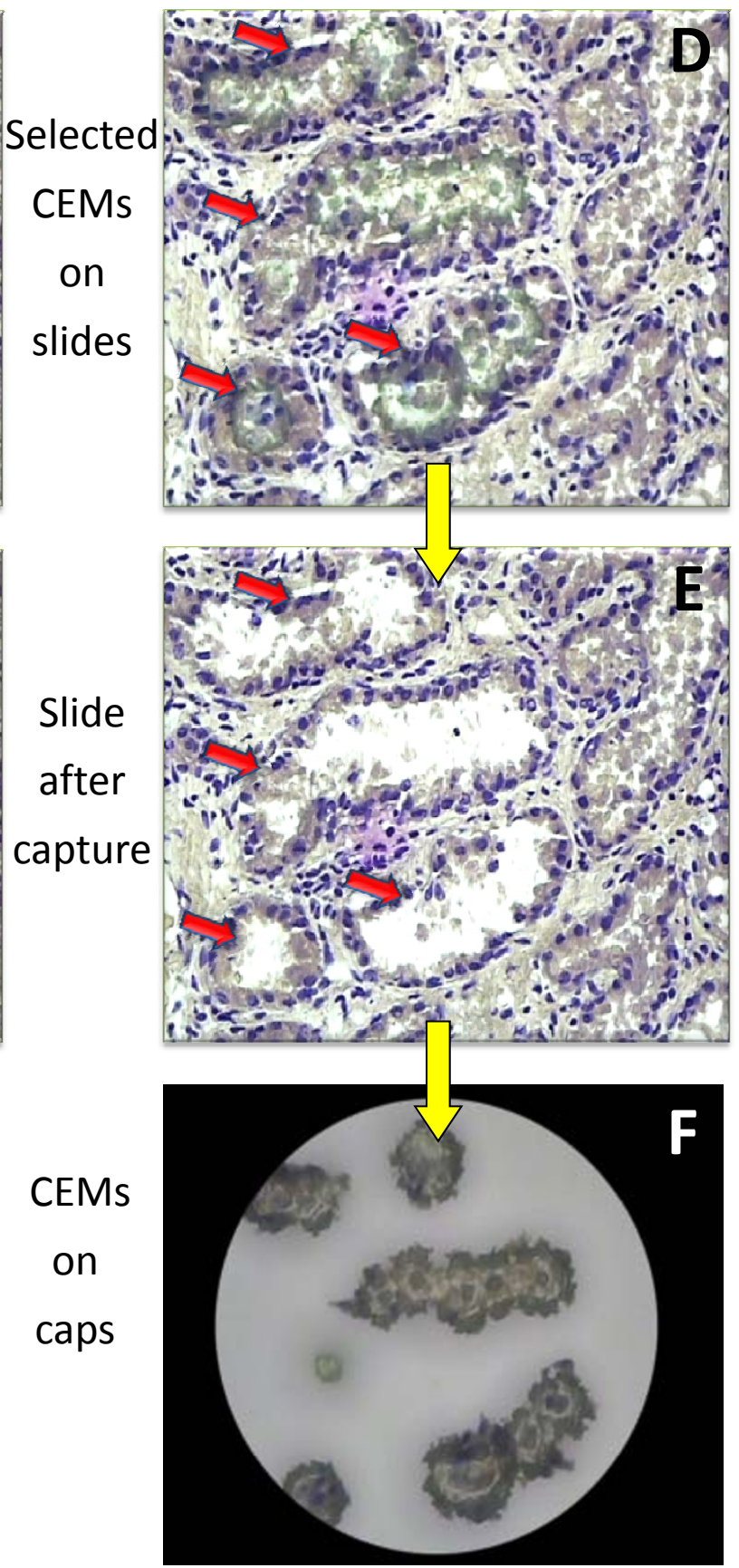

Amount of RNA: 5 to $10 \mathrm{ng}$

Figure 2 Impact of glass slide temperature on cell transfer efficiency and RNA extraction yield. Frozen tissues cut at $8 \mu \mathrm{m}$ and transferred on glass slides that have been placed at room temperature (A) or chilled and kept at $4^{\circ} \mathrm{C}$, before transfer (D). As evidenced by the number of cells captured ( $C$ and F) and the RNA yield, given under each cap ( $C$ and F) the efficiency of capture was very low for the slides placed at room temperature. A/D: Cresyl violet ${ }^{\oplus}$ stained slides before LCM; red arrows indicate the thermoplastic film stuck on epithelial cells to be captured. B/E: mammary tissue section remaining on the glass slide after LCM. C/F: microdissected mammary epithelial cells transferred on the LCM cap. 


\section{Thickness of Cryo-sections, slide temperature}

Tissue was cut at 6,8 and $10-\mu \mathrm{m}$ thickness. The best compromise for obtaining a sufficient amount of material while preserving tissue morphology was $8-\mu \mathrm{m}$ thickness. Temperature of the slide before sectioning and transferring the tissue section on the slide also appeared to be critical (Figure 2). Whatever the protocol subsequently applied for slide fixation and staining an optimal temperature difference of $20-25^{\circ} \mathrm{C}$ between the cryostat and the glass slide is required to succeed in capture. The most efficient transfer was obtained by keeping slides on ice or in a refrigerator before use. This parameter seems to be crucial since the amount of RNA extracted can reach up to a 15 -fold increase, varying between 10-15 ng for cold slides vs. 0-1 ng for slides kept at room temperature.

It is difficult to evaluate the exact number of MEC isolated after 40 to $60 \mathrm{~min}$ of LCM since this it depends on the number of acini present on the slide and on the MEC per acini (10 to >40). Given that the Veritas Arcturus system allows quantification of captured material via a tool estimating the total area selected before capture, we can establish a correlation between captured area $\left(\mathrm{mm}^{2}\right)$ and RNA quantity. Usually, with goat and cow samples, we get 5 to 10 ng of RNA per cap ( $c a$. 300,000 to $600,000 \mu \mathrm{m}^{2}$ of captured cells, corresponding to more or less 2500 cells: 150 alveoli $\times 25$ cell sections in average per acinus). In other words, there are 3 picog RNA in $1 / 3$ cell since we work on $8-\mu \mathrm{m}$ tissue section thickness, and therefore one can estimate to $c a .10$ picog the amount of RNA contained in one MEC. However with sheep, the amount of material we obtained was between 1.5 and 2 times higher.

\section{Storage conditions of slides}

We also tested the possibility of keeping the slide with tissue sections in cold $75 \%$ ethanol at $-20^{\circ} \mathrm{C}$ in order to find conditions stabilizing mammary tissue sections for a long period, before LCM treatment. We observed that in this way we did not impact capture efficiency and stabilized tissue sections from few hours before treatment to several days, even one week. We also tested whether tissue sections on slides can be stored at $-80^{\circ} \mathrm{C}$ for several days. Slides were put into $50 \mathrm{ml}$ Falcon tubes with desiccant, quickly placed in dry ice and stock at $-80^{\circ} \mathrm{C}$. We observed that morphology and RNA quality were not affected although the quantity of captured material was always very poor. In conclusion, we choose to put slides in cold $75 \%$ ethanol at $-20^{\circ} \mathrm{C}$ until the staining step.

\section{Staining and dehydration impact on RNA yield and integrity}

The next step was to evaluate the impact of fixation, staining and dehydration on RNA integrity and yield as well as on tissue morphology. Previous studies $[37,38,44]$ have shown that these steps are crucial for obtaining good and reproducible results, regardless the kind of tissue. We compared two staining conditions commonly used for LCM studies (Ambion, LCM staining kit with Cresyl Violet ${ }^{\circ}$ stain solution and Arcturus HistoGene ${ }^{\circ}$ kit with Histogene stain solution) and different times of dehydration. HistoGene ${ }^{\circ}$ stain is a special solution developed by Arcturus to stain tissues for LCM subsequently used as sources of RNA. It is a fast penetrating stain that provides good contrast by differential staining of nuclei (purple) and cytoplasm (light pink). Cresyl Violet ${ }^{\circ}$ is a hydrophilic, basic stain that binds to negatively charged nucleic acids without water step during slide preparation to re-hydrate the tissue.

Results are given in Table 1 and Figure 3. The best morphology was obtained with HistoGene following the protocol recommended by Arcturus, $\left(\mathrm{N}^{\circ} 1\right)$ which easily distinguished the cytoplasm (stained in brown) and the nucleus (stained in blue, Figure 3A). However, we observed significant variations in RNA quality (RIN value ranging between 6.5 and 3) across serial slides prepared from the same bloc of tissue whereas the RIN value obtained with RNA extracted from the whole tissue was 8.5. To reduce RNA degradation, we eliminated water steps before and after staining (protocol $\mathrm{N}^{\circ} 2$ ). Stain penetration was then lower, allowing however MEC to still be easily recognized, and limiting RNA degradation significantly as compared with protocol $\mathrm{N}^{\circ} 1$ although RNA quality was still non reproducible. We hypothesized that HistoGene $^{\circ}$ can accelerate degradation by reactivation of endogenous nucleases present in mammary gland, likely due to $\mathrm{pH}$ of HistoGene ${ }^{\bullet}$ solution ( $\mathrm{pH}$ measured $~ 4.0$ ), whereas neutral $\mathrm{pH}$ of Cresyl violet ${ }^{\circ}$ solution $(\mathrm{pH}$ measured $~ 7$ ) avoids degradation of RNA. After substitution of HistoGene ${ }^{\circ}$ by RNase-free water (protocol $\mathrm{N}^{\circ} 8$ ), RNA degradation was reduced by less than one RIN unit. However, it was obviously not possible to recognize cells on unstained tissue sections. Given these results we decided to use the Cresyl violet ${ }^{\circ}$ as stain for further experiments.

Dehydration is crucial to stabilize the tissue and to allow capture. All the steps following dehydration (identification and selection of areas of interest, adjusting laser parameters and capture) are time consuming and it is necessary to keep tissues dehydrated to avoid degradation of RNA. A high ambient humidity could rehydrate the tissue and reactivate endogenous RNases. In addition, moisture impedes film adhesion and cell capture. For these reasons, we limit LCM to 45-60 minutes which proved to be a good compromise to overcome the variations in relative humidity. Ordway et al. [45] recently showed the detrimental effect of relative humidity of the laboratory where tissue sections are stained, handled, and submitted to LCM, thus impacting 


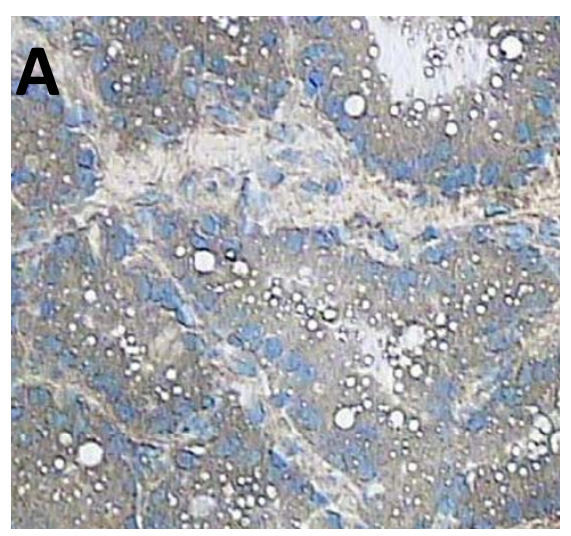

Protocols 1/2 : $-\Delta$ RIN: 3.5 to 6

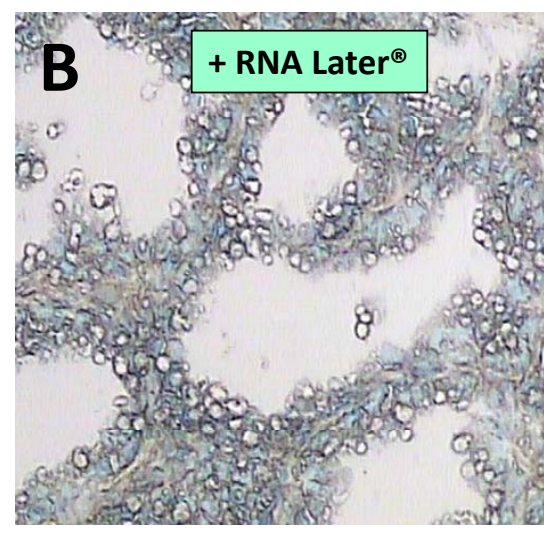

Protocol 3 : - $\Delta$ RIN: 2

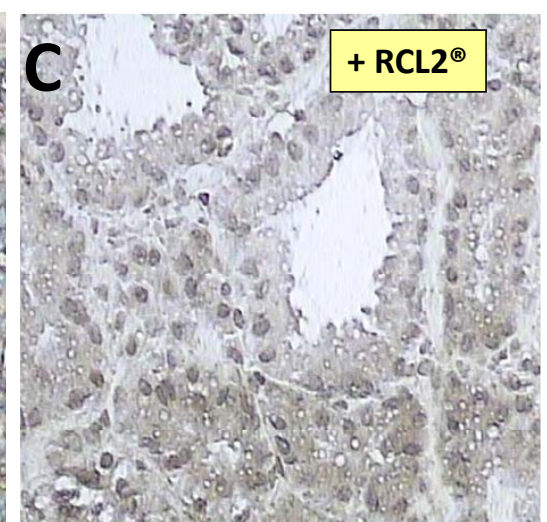

Protocol 4 : - $\Delta$ RIN: 2 to 3

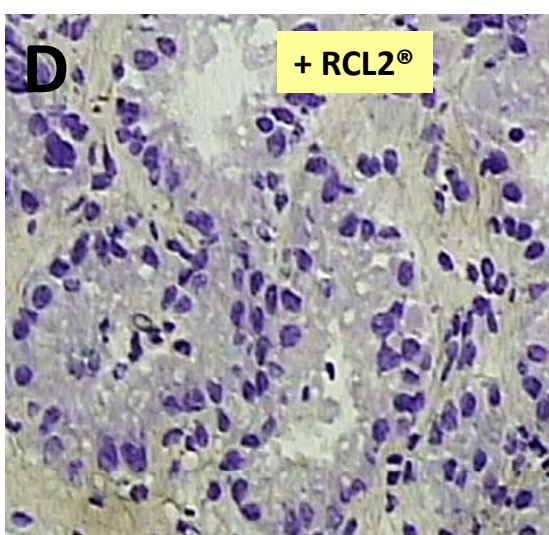

Protocol 5 : - $\Delta$ RIN: 0.5 to 1

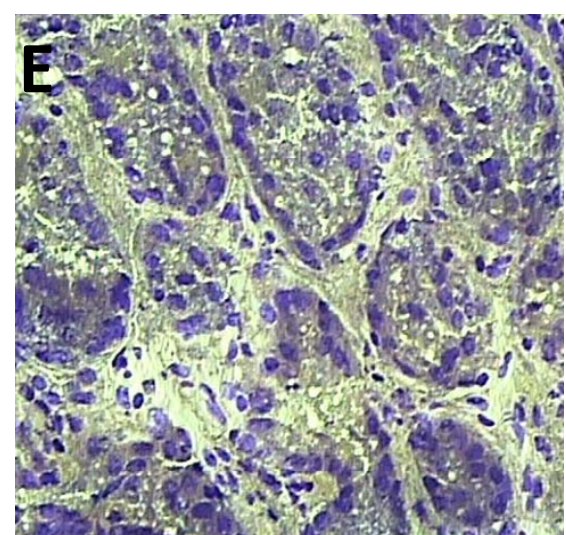

Protocols 6/7: $-\Delta$ RIN: 0.5 to 1

Figure 3 Impact of histological stain and fixative/protector on morphology of goat mammary tissue and RNA integrity. Frozen mammary tissue sections were stained either with HistoGene ${ }^{\oplus}$ (A to $C$ ) or with Cresyl violet ${ }^{\oplus}$ ( $D$ and $E$ ). MEC isolated after treatment with RCL2, a new fixative preserving tissue morphology and Nucleic Acid integrity (C and D), or with RNA later (B) provide RNA of better quality, expressed as $\triangle R I N$ which is difference between the RIN value obtained with total RNA extracted from the mammary tissue section (8.5) and the RIN value obtained with RNA extracted from microdissected cells.

the performance of the instrument and the quality of RNA extracted from tissue sections. Low relative humidity in the laboratory (lower than $23 \%$ ), was conducive to little or no degradation of RNA extracted from tissue following staining and fixation and to high capture efficiency by the LCM instrument. Clément-Ziza et al. have proposed to perform LCM under an argon atmosphere, thus preventing tissue rehydration to finally stabilize RNA [44]. These authors have also assessed several staining solutions in regard of their effect on tissue morphology and RNA integrity. They have noticed that stains that were very efficient when dissolved in water, such as hematoxylin and eosin $\mathrm{B}$, are faint or poorly resolutive in alcoholic solvent. They also observed significant RNA degradation when alcoholic staining solutions containing hematoxylin were used. On the other hand, the cresyl violet in ethanolic solution seems to be appropriate to perform LCM experiments as shown in our study on the mammary tissue.

\section{Fixatives and RNA protectors: impact on Yield and} Integrity of RNA

Following these results, we hypothesized that addition of RNA protectors (RNase inhibitors) such as RNA later ${ }^{\circ}$ (protocol $\mathrm{N}^{\circ} 3$ ) or $\mathrm{RCL}_{2}{ }^{\circ}$, are promising new noncrosslinking fixatives [46], preserving morphology and nucleic acid integrity (protocols $\mathrm{N}^{\circ} 4$ ) before HistoGene ${ }^{\circ}$ staining and could improve RNA quality. Actually, RNA degradation was especially reduced with RNA later ${ }^{\circ}$ (loss of one RIN unit) whereas with RCL2 $^{\circ}$ we observed a loss of 1.5 to 2.5 RIN units. However, RNA later ${ }^{\circledR}$ provokes a loss in morphology (Figure $3 \mathrm{~B}$, protocol $\mathrm{N}^{\circ} 3$ ) compared with $\mathrm{RCL}^{\circ}$ (Figure $3 \mathrm{C}$, protocol $\mathrm{N}^{\circ} 4$ ). Therefore, $\mathrm{RCL} 2^{\circ}$ provides a good compromise to get morphology and RNA quality. The same test was carried out with Cresyl violet ${ }^{\circ}$ (Figure 3D, protocol $\mathrm{N}^{\circ} 5$ ). We found that this stain did not affect RNA integrity, and addition of RNA protector was without any effect. In fact, with or without protector, loss of RIN units was 
less than 1. Morphologically, the acini were well identified with Cresyl violet ${ }^{\circ}$ and RCL2 $2^{\circ}$ slightly improved the image.

RNasin (Promega, France), a potent inhibitor of ribonucleases, was also tested prior to staining since such inhibitory activity was reported to protect RNA (included in staining solution) from degradation in LCM experiments for gene expression profiling of basal cell cancer tissues $[47,48]$. We did not observed any significant improvement in quality (RIN scores) of RNA recovered from mammary tissue sections treated in such a way.

Nevertheless, there was no considerable improvement in either quality or quantity of RNA recovered from the tissue sections after an inhibitor treatment. In conclusion, we finally decided to opt for protocol $\mathrm{N}^{\circ} 7$ (without any RNA protector) which is easier to handle and quicker to perform.

\section{MEC enrichment by LCM: contamination by MMC and immune cells}

qPCR experiments were performed on reverse transcribed RNA extracted from microdissected cells targeting specific gene transcripts to evaluate enrichment in MEC.

To determine potential cell contamination of the laser-captured cells by adjacent MMC or to estimate the selective capture of MEC, mRNA transcript levels of cell-specific markers were assessed by evaluating the relative expression between captured cells and their corresponding mammary tissue scrapes, after LCM. Relative quantity with specific markers for MMC (Krt14) and MEC (LALBA and CSN1S2) was assessed after normalization, using PPAI and/or RPS24 as reference genes. $F A S N$, a gene expressed in a large panel of tissues [49] including several cell types mainly in cells with high lipid metabolism such as adipocytes, hepatocytes but also in fetal proliferative epithelial cells and MEC, was also assessed under the same conditions. Levels of LALBA $(\mathrm{RQ}$ mean $=1.47), C S N 1 S 2(\mathrm{RQ}$ mean $=1.33)$ were significantly increased. FASN was relatively unchanged $(R Q$ mean $=0.85)$, suggesting that active fatty acid synthesis which is required for energy utilization and membrane synthesis is equally expressed in MEC and in the surrounding tissue. These results attest to the enrichment in MEC after LCM even though increasing in LALBA and CSN1S2 transcripts are less striking, given the high percentage of MEC (around 80$90 \%$ ) and the low number of other cell types in lactating mammary parenchyma sections.

Significant results were recorded when quantifying messengers from genes specific for other cell types such as MMC and immune cells. Thus, levels of Krt14 messengers decreased dramatically $(\mathrm{RQ}=0.14 ; c a$. 7 -folds reduction) in the captured cells compared with the whole mammary tissue. A weak expression of Krt-14 was systematically observed in microdissected MEC, reflecting a slight contamination by MMC during capture. This is due to a very close proximity between MMC and MEC [50,51] as shown in confocal images of a breast section double-stained for both cell types where double-stained suprabasal cells are occasionally found [52]. Similar results were obtained with $C D 3 e$ (RQ mean $=0.14$ ), a marker of lymphocytes and CD68 (RQ mean $=0.18$ ) which suggests the putative presence of macrophages (Figure 4), further demonstrating the efficiency of LCM.

High standard deviations were observed for these qPCR experiments, pointing out the degree of confidence that can be given to the results in terms of statistical conclusions. It must be kept in mind that gene expression measurement techniques such as qPCR not only require a normalization strategy to allow meaningful comparisons between biological samples [53], but also demands work with RNA of good quality (RIN > 7), in sufficient amount and that genes for which the expression is measured must be expressed at a sufficient level.

Typically, all these parameters have to be considered and the first one is usually accomplished through the use of endogenous housekeeping genes that are presumed to show stable expression levels in the samples under study. Which specific genes and how they can be measured in limited amounts of mRNA such as those extracted from microdissected cells still remains a concern. GeNorm software confirmed that PPAI and RPS24 are actually highly reliable reference genes for normalization purposes. To calibrate input amounts of starting material, cell count and/or total RNA are useful but they are not precise enough and reliable enough to serve as normalization standards. Demonstrating relative enrichment in one cell type after microdissection is difficult since we start from heterogeneous tissues. Therefore, what calibrator (tissue scrapes or whole tissue) to use to perform relative gene expression measurements made by qPCR? We chose to use isolated cells (each cap) against all scrape sections since it can be considered as a mean value of serial tissue sections.

\section{Conclusions}

LCM makes it possible to obtain highly MEC enriched material from lactating mammary tissue sections preserving RNA integrity. In addition, we provide molecular evidence for successful selectivity of the capture method despite the difficulty of disassociating luminal secretory cells (MEC) from MMC bordering the basal lamina which separates the epithelial layer from the extracellular matrix. 


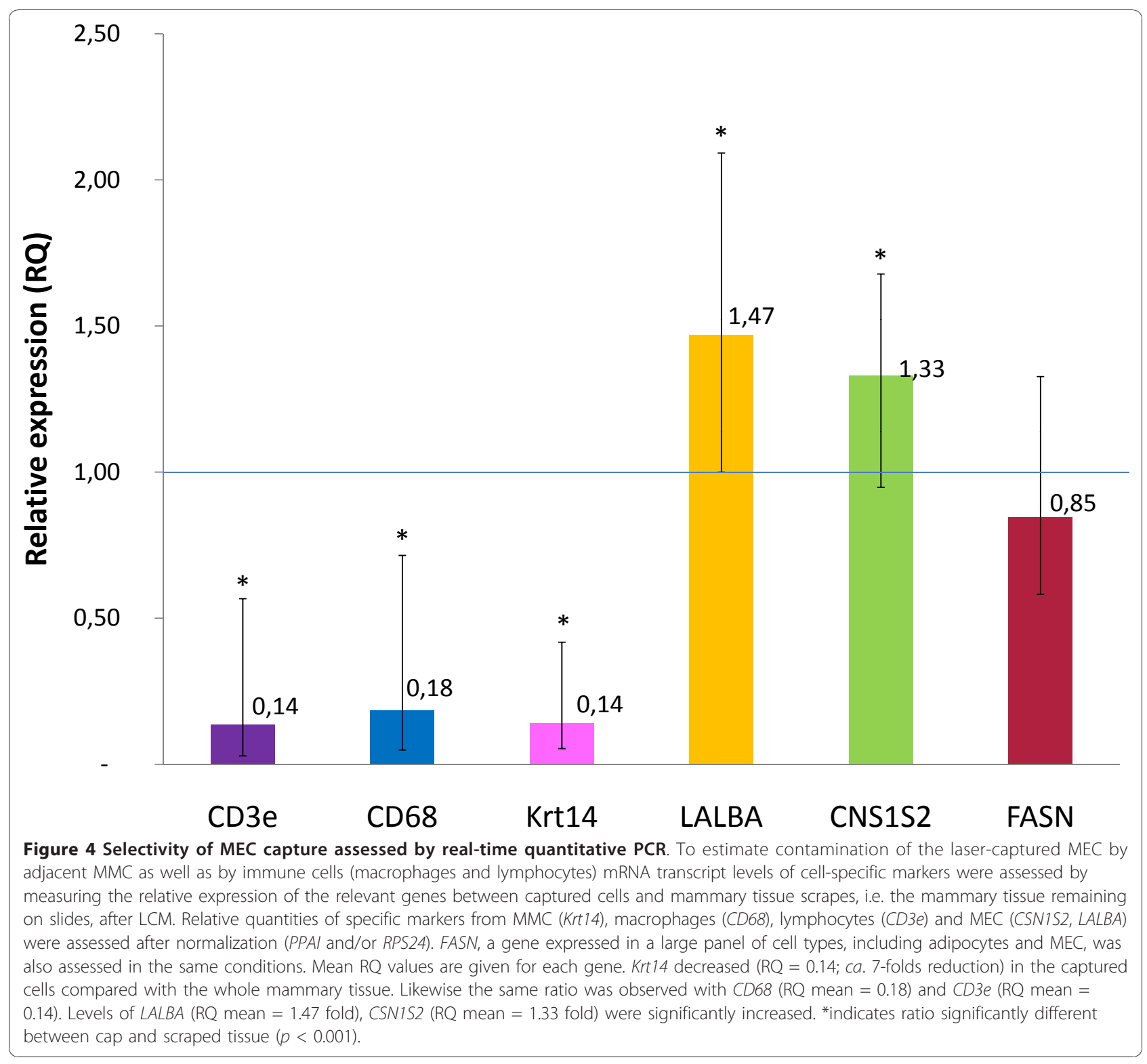

To accurately evaluate the expression of genes specifically expressed in MEC, such as those encoding LALBA and CSN1S2 represents a step forward in determining the transcriptional profile of a cell type and how it can be modulated by environmental factors such as feeding, stress, milking frequency, the health status or gene polymorphisms. In addition, to understand how genes expressed in several cell types are regulated, it is crucial to work on pure or at least enriched cell populations. Otherwise, expression analyses could potentially lead to artefactual results. This is well-exemplified by FASN, a gene encoding the fatty acid synthase which is widely expressed in many tissues and cell types, including the alveolar secretory epithelium and adipose tissue. Relative proportions of these tissues, both involved in lipid metabolism, dramatically change during pregnancy.

Capturing other cell types or stroma provides the opportunity to examine further to understand the mechanisms involved in growth regulation and morphogenesis of the mammary gland. Until now, most attention has been paid to the luminal epithelial cell which is the functionally active milk-producing cell and the most likely target cell for carcinogenesis. However attention on myoepithelial cells has begun to evolve with the recognition that these cells play an active part in branching morphogenesis and tumor suppression [54]. However, the major question remains to know how the luminal epithelial and myoepithelial lineages are related 
and how they arise from a common putative stem cell population. Xenotransplantation in mice and comparative studies across species (ruminants and humans), have shown that the fat pad plays a crucial role in mammogenesis [3]. Furthermore, it was observed in ruminants that during pregnancy, stroma would contribute to mechanisms that regulate growth. This could be extrapolated to other species, especially women and mice for which fat remains important, even during lactation. However, the greatest challenge remains to assess the contribution of local mechanisms that regulate growth which may explain the range in tumorogenic susceptibility of the mammary gland between species. Since information obtained from rodents may not always be directly transposed to the human breast and that ruminants show a morphology and mammary parenchyma development similar to humans, ruminants remain a pertinent model to go further into mammary gland biology understanding. Capturing different cell types makes it possible to establish cell specific gene expression profiles from healthy tissue, useful for discovering new tumor biomarkers.

\section{List of Abbreviations}

qPCR: real time quantitative Polymerase Chain Reaction; MEC: Mammary Epithelials Cell; MMC: Mammary Myoepithelial Cell; RIN: RNA Integrity Number; RQ: Relative Quantification; RPS24: Ribosomal Protein S24; PPIA: cyclophylin A; Krt14: Cytokeratin 14; FASN: Fatty Acid Synthase; CSN1S2: $\alpha_{s 2}$-casein; LALBA: $\alpha$-lactalbumin;

\section{Acknowledgements}

We thank Cathy Hue-Beauvais and Stéphane Bouet for helpful assistance and advices for cryosection and Christine Longin from the local microscopy platform (Mima2) for providing a valuable technical environment. We warmly thank Juan Fernando Medrano for helpful comments and advice and review of this manuscript. We also appreciatively thank Pauline Brenaut for her contribution to design some GPCR systems and help in $\mathrm{QPCR}$ analyses. We would like also to acknowledge peoples from experimental farms involved in the care of animals and tissue sample collection required for this study, especially the UCEA team (J.-P. Aubert and D. Mauchand, from INRA, Centre de Recherches de Jouy-en-Josas), the UEPAO team (INRA, Centre de Recherches de Nouzilly) and F. Bouvier (UE 332, Domaine de Bourges), and H. Caillat (INRA, UR631, Castanet Tolosan). This research was supported by the Agence Nationale pour la Recherche (ANR) and by the Groupement d'Intérêt Scientifique APIS Gene (programme Genomilk Fat).

\section{Author details}

${ }^{1}$ INRA, UMR1313 Unité Génétique Animale et Biologie Intégrative, équipe « Lait, Génome \& Santé » F-78350 Jouy-en-Josas, France. ${ }^{2}$ INRA-Plateforme ICE (Iso Cell Express), F-78350 Jouy-en-Josas, France. ${ }^{3}$ Excilone SARL, Microgenomic services, F-78490 Vicq, France. ${ }^{4}$ UMR1286 PsyNuGen Unité de Psychoneuroimmunologie, Nutrition et Génétiquelnstitut François Magendie 146 rue Léo Saignat 33077 BORDEAUX CEDEX.

\section{Authors' contributions}

CB participated in study design, performed the LCM, RNA extraction and QPCR experiments, including statistical analyses, and drafted the manuscript. SM helped to perform the LCM and RNA extraction. JCH helped to perform qPCR and contributed to design qPCR systems. PD contributed to LCM protocol optimization. PM conceived the study and participated in its design and coordination and helped to draft the manuscript. All authors read and approved the final manuscript.
Received: 6 September 2010 Accepted: 6 December 2010 Published: 6 December 2010

\section{References}

1. Chanat E, Aujean E, Balteanu A, Chat S, Coant N, Fontaine ML, HueBeauvais C, Pechoux C, Torbati MB, Pauloin A, et al: [Nuclear organization and expression of milk protein genes]. J Soc Biol 2006, 200(2):181-192.

2. Heid HW, Keenan TW: Intracellular origin and secretion of milk fat globules. Eur J Cell Biol 2005, 84(2-3):245-258.

3. Hovey RC, McFadden TB, Akers RM: Regulation of mammary gland growth and morphogenesis by the mammary fat pad: a species comparison. $J$ Mammary Gland Biol Neoplasia 1999, 4(1):53-68.

4. Rudolph MC, MCManaman JL, Hunter L, Phang T, Neville MC: Functional development of the mammary gland: use of expression profiling and trajectory clustering to reveal changes in gene expression during pregnancy, lactation, and involution. J Mammary Gland Biol Neoplasia 2003, 8(3):287-307.

5. Rudolph MC, McManaman JL, Phang T, Russell T, Kominsky DJ, Serkova NJ, Stein T, Anderson SM, Neville MC: Metabolic regulation in the lactating mammary gland: a lipid synthesizing machine. Physiol Genomics 2007, 28(3):323-336.

6. Anderson SM, Rudolph MC, McManaman JL, Neville MC: Key stages in mammary gland development. Secretory activation in the mammary gland: it's not just about milk protein synthesis! Breast Cancer Res 2007, 9(1):204.

7. Faucon F, Rebours E, Bevilacqua C, Helbling JC, Aubert J, Makhzami S, Dhorne-Pollet S, Robin S, Martin P: Terminal differentiation of goat mammary tissue during pregnancy requires the expression of genes involved in immune functions. Physiol Genomics 2009, 40(1):61-82.

8. Grigoriadis A, Mackay A, Reis-Filho JS, Steele D, Iseli C, Stevenson BJ, Jongeneel CV, Valgeirsson $\mathrm{H}$, Fenwick $\mathrm{K}$, Iravani $\mathrm{M}$, et al: Establishment of the epithelial-specific transcriptome of normal and malignant human breast cells based on MPSS and array expression data. Breast Cancer Res 2006, 8(5):R56.

9. Fuller AP, Palmer-Toy D, Erlander MG, Sgroi DC: Laser capture microdissection and advanced molecular analysis of human breast cancer. J Mammary Gland Biol Neoplasia 2003, 8(3):335-345.

10. Murphy N, Millar E, Lee CS: Gene expression profiling in breast cancer: towards individualising patient management. Pathology 2005, 37(4):271-277.

11. Sasano H, Miki Y, Nagasaki S, Suzuki T: In situ estrogen production and its regulation in human breast carcinoma: from endocrinology to intracrinology. Pathol Int 2009, 59(11):777-789.

12. Balogh GA, Heulings R, Mailo DA, Russo PA, Sheriff F, Russo $\mathbb{H}_{\text {, Moral }}$, Russo J: Genomic signature induced by pregnancy in the human breast. Int J Oncol 2006, 28(2):399-410.

13. Zhu Z, Jiang W, McGinley JN, Price JM, Gao B, Thompson HJ: Effects of dietary energy restriction on gene regulation in mammary epithelial cells. Cancer Res 2007, 67(24):12018-12025.

14. Bartley JC, Emerman JT, Bissell MJ: Metabolic cooperativity between epithelial cells and adipocytes of mice. Am J Physiol 1981, 241(5): C204-208.

15. Rudolph MC, Wellberg EA, Anderson SM: Adipose-depleted mammary epithelial cells and organoids. J Mammary Gland Biol Neoplasia 2009, 14(4):381-386.

16. Clarke C, Titley J, Davies S, O'Hare MJ: An immunomagnetic separation method using superparamagnetic (MACS) beads for large-scale purification of human mammary luminal and myoepithelial cells. Epithelial Cell Biol 1994, 3(1):38-46.

17. Gomm JJ, Browne PJ, Coope RC, Liu QY, Buluwela L, Coombes RC: Isolation of pure populations of epithelial and myoepithelial cells from the normal human mammary gland using immunomagnetic separation with Dynabeads. Anal Biochem 1995, 226(1):91-99.

18. Alcorn J, Lu X, Moscow JA, McNamara PJ: Transporter gene expression in lactating and nonlactating human mammary epithelial cells using realtime reverse transcription-polymerase chain reaction. J Pharmacol Exp Ther 2002, 303(2):487-496.

19. Boutinaud M, Ben Chedly MH, Delamaire E, Guinard-Flament J: Milking and feed restriction regulate transcripts of mammary epithelial cells purified from milk. J Dairy Sci 2008, 91(3):988-998. 
20. O'Hare MJ, Ormerod MG, Monaghan P, Lane EB, Gusterson BA: Characterization in vitro of luminal and myoepithelial cells isolated from the human mammary gland by cell sorting. Differentiation 1991 46(3):209-221.

21. Hayashi AA, McCoard SA, Roy NC, Barnett MPG, Mackenzie DDS, McNabb WC: Gene expression in bovine mammary somatic cells isolated from milk. Journal Animal Feed Science 2004, 13:401-404

22. Murrieta CM, Hess BW, Scholljegerdes EJ, Engle TE, Hossner KL, Moss GE, Rule DC: Evaluation of milk somatic cells as a source of mRNA for study of lipogenesis in the mammary gland of lactating beef cows supplemented with dietary high-linoleate safflower seeds. J Anim Sci 2006, 84(9):2399-2405.

23. Dundas SR, Ormerod MG, Gusterson BA, O'Hare MJ: Characterization of luminal and basal cells flow-sorted from the adult rat mammary parenchyma. J Cell Sci 1991, 100(Pt 3):459-471

24. Keenan TW: Historical Perspective: Milk Lipid Globules and Their Surrounding Membrane: A Brief History and Perspectives for Future Research. Journal of mammary gland biology and neoplasia 2001, 6(3):365-371.

25. Hallowes RC, Rudland PS, Hawkins RA, Lewis DJ, Bennet D, Durbin H: Comparison of the effects of hormones on DNA synthesis in cell cultures of nonneoplastic and neoplastic mammary epithelium from rats. Cancer Res 1977, 37(8 Pt 1):2492-2504.

26. Richards J, Nandi S: Primary culture of rat mammary epithelial cells. I. Effect of plating density, hormones, and serum on DNA synthesis. J Natl Cancer Inst 1978, 61(3):765-771.

27. Ceriani RL: Fetal mammary gland differentiation in vitro in response to hormones. I. Morphological findings. Dev Biol 1970, 21(4):506-529.

28. Hamamoto S, Imagawa W, Yang J, Nandi S: Morphogenesis of mouse mammary epithelial cells growing within collagen gels: ultrastructural and immunocytochemical characterization. Cell Differ 1988, 22(3):191-201.

29. Barcellos-Hoff MH, Aggeler J, Ram TG, Bissell MJ: Functional differentiation and alveolar morphogenesis of primary mammary cultures on reconstituted basement membrane. Development 1989, 105(2):223-235.

30. Guzman RC, Osborn RC, Bartley JC, Imagawa W, Asch BB, Nandi S: In vitro transformation of mouse mammary epithelial cells grown serum-free inside collagen gels. Cancer Res 1987, 47(1):275-280.

31. Richards J, Nandi S: Primary culture of rat mammary epithelial cells. II. Cytotoxic effect and metabolism of 7,12-dimethylbenz[a]anthracene and N-nitroso-N-methylurea. J Natl Cancer Inst 1978, 61(3):773-777.

32. Medina D, Lane HW, Tracey CM: Selenium and mouse mammary tumorigenesis: an investigation of possible mechanisms. Cancer Res 1983, 43(5 Suppl):2460s-2464s.

33. Warburton MJ, Ferns SA, Hughes CM, Rudland PS: Characterization of rat mammary cell types in primary culture: lectins and antisera to basement membrane and intermediate filament proteins as indicators of cellular heterogeneity. J Cell Sci 1985, 79:287-304.

34. Ernens I, Clegg R, Schneider YJ, Larondelle Y: Short communication: Ability of cultured mammary epithelial cells in a bicameral system to secrete milk fat. J Dairy Sci 2007, 90(2):677-681.

35. Emmert-Buck MR, Bonner RF, Smith PD, Chuaqui RF, Zhuang Z, Goldstein SR, Weiss RA, Liotta LA: Laser capture microdissection. Science 1996, 274(5289):998-1001.

36. Goldsworthy SM, Stockton PS, Trempus CS, Foley JF, Maronpot RR: Effects of fixation on RNA extraction and amplification from laser capture microdissected tissue. Mol Carcinog 1999, 25(2):86-91.

37. Kerman IA, Buck BJ, Evans SJ, Akil H, Watson SJ: Combining laser capture microdissection with quantitative real-time PCR: effects of tissue manipulation on RNA quality and gene expression. J Neurosci Methods 2006, 153(1):71-85.

38. Wang H, Owens JD, Shih JH, Li MC, Bonner RF, Mushinski JF: Histological staining methods preparatory to laser capture microdissection significantly affect the integrity of the cellular RNA. BMC Genomics 2006, 7:97.

39. Schroeder A, Mueller O, Stocker S, Salowsky R, Leiber M, Gassmann M, Lightfoot S, Menzel W, Granzow M, Ragg T: The RIN: an RNA integrity number for assigning integrity values to RNA measurements. BMC Mol Biol 2006, 7:3

40. Bevilacqua C, Helbling JC, Miranda G, Martin P: Translational efficiency of casein transcripts in the mammary tissue of lactating ruminants. Reprod Nutr Dev 2006, 46(5):567-578.
41. Bustin SA, Benes V, Garson JA, Hellemans J, Huggett J, Kubista M, Mueller R, Nolan T, Pfaffl MW, Shipley GL, et al: The MIQE guidelines: minimum information for publication of quantitative real-time PCR experiments. Clin Chem 2009, 55(4):611-622.

42. Vandesompele J, De Preter K, Pattyn F, Poppe B, Van Roy N, De Paepe A, Speleman F: Accurate normalization of real-time quantitative RT-PCR data by geometric averaging of multiple internal control genes. Genome Biol 2002, 3(7):RESEARCH0034.

43. Pfaffl MW, Horgan GW, Dempfle L: Relative expression software tool (REST) for group-wise comparison and statistical analysis of relative expression results in real-time PCR. Nucleic Acids Res 2002, 30(9):e36.

44. Clément-Ziza M, Munnich A, Lyonnet S, Jaubert F, Besmond C: Stabilization of RNA during laser capture microdissection by performing experiments under argon atmosphere or using ethanol as a solvent in staining solutions. Rna 2008, 14(12):2698-2704.

45. Ordway GA, Szebeni A, Duffourc MM, Dessus-Babus S, Szebeni K: Gene expression analyses of neurons, astrocytes, and oligodendrocytes isolated by laser capture microdissection from human brain: detrimental effects of laboratory humidity. J Neurosci Res 2009, 87(11):2430-2438.

46. Delfour $C$, Roger $P$, Bret C, Berthe ML, Rochaix P, Kalfa N, Raynaud P, Bibeau F, Maudelonde T, Boulle N: RCL2, a new fixative, preserves morphology and nucleic acid integrity in paraffin-embedded breast carcinoma and microdissected breast tumor cells. J Mol Diagn 2006, 8(2):157-169.

47. Micke P, Östman A, Lundeberg J, Ponten F: Laser-Assisted Cell Microdissection using the PALM System. In Methods in Molecular Biology, Laser Capture Microdissection: Methods and Protocols. Volume 293. Edited by: Murray Gl, Currun S. (c) Human Press inc, Totowa, NJ; 2005:151-166.

48. Kube DM, Savci-Heijink CD, Lamblin AF, Kosari F, Vasmatzis G, Cheville JC, Connelly DP, Klee GG: Optimization of laser capture microdissection and RNA amplification for gene expression profiling of prostate cancer. BMC Mol Biol 2007, 8:25.

49. Kusakabe T, Maeda M, Hoshi N, Sugino T, Watanabe K, Fukuda T, Suzuki T: Fatty acid synthase is expressed mainly in adult hormone-sensitive cells or cells with high lipid metabolism and in proliferating fetal cells. $J$ Histochem Cytochem 2000, 48(5):613-622.

50. Emerman JT, Vogl AW: Cell size and shape changes in the myoepithelium of the mammary gland during differentiation. Anat Rec 1986, 216(3):405-415.

51. Stingl J, Raouf A, Emerman JT, Eaves CJ: Epithelial progenitors in the normal human mammary gland. J Mammary Gland Biol Neoplasia 2005, 10(1):49-59.

52. Pechoux C, Gudjonsson T, Ronnov-Jessen L, Bissell MJ, Petersen OW: Human mammary luminal epithelial cells contain progenitors to myoepithelial cells. Dev Biol 1999, 206(1):88-99.

53. Erickson HS, Albert PS, Gillespie JW, Rodriguez-Canales J, Marston Linehan W, Pinto PA, Chuaqui RF, Emmert-Buck MR: Quantitative RT-PCR gene expression analysis of laser microdissected tissue samples. Nat Protoc 2009, 4(6):902-922.

54. Gudjonsson T, Adriance MC, Sternlicht MD, Petersen OW, Bissell MJ: Myoepithelial cells: their origin and function in breast morphogenesis and neoplasia. J Mammary Gland Biol Neoplasia 2005, 10(3):261-272.

doi:10.1186/1471-2121-11-95

Cite this article as: Bevilacqua et al:: Maintaining RNA integrity in a

homogeneous population of mammary epithelial cells isolated by Laser Capture Microdissection. BMC Cell Biology 2010 11:95. 